\title{
Induction of oestrus and ovulation in anoestrous fallow deer (Dama dama) by using progesterone and GnRH treatment
}

\author{
G. W. Asher and K. L. Macmillan \\ Ruakura Animal Research Station, Ministry of Agriculture \& Fisheries, Private Bag, Hamilton, \\ New Zealand
}

\begin{abstract}
Summary. Fourteen seasonally anoestrous, non-lactating fallow does were each treated with an intravaginal progesterone device for 14 days followed by a subcutaneously implanted osmotic minipump delivering synthetic $\mathrm{GnRH}$ at doses of $125 \mathrm{ng} / \mathrm{h}$ ( 7 does) or $250 \mathrm{ng} / \mathrm{h}$ ( 7 does) for up to 7 days, about 6 weeks before the natural breeding season. One doe (low delivery rate) lost its intravaginal device and 6 of the remaining does $(46.2 \%)$ exhibited oestrus between 71 and $120 \mathrm{~h}$ after progesterone withdrawal/ minipump insertion. Only one of these does received the low GnRH delivery rate and 5 received the high rate. Serum progesterone profiles indicated that an induced oestrus was followed by apparently normal luteal development. Does which did not exhibit oestrus failed to show a luteal response. Only 1 doe conceived at induced oestrus, producing a viable female fawn 6 weeks before the start of the natural fawning season. The remaining does returned to an anoestrous state until the onset of the natural breeding season.
\end{abstract}

\section{Introduction}

Fallow deer (Dama dama) are highly seasonal breeders with does exhibiting oestrus in autumn following a period of seasonal and/or lactational anoestrus in summer (Chapman \& Chapman, 1975). First oestrus occurs within a 12-14-day period in late April and early May in New Zealand, and the transition from anoestrus to oestrus is characterized by the occurrence of one or more silent ovulations associated with a short-lived corpus luteum (Asher, 1985). Recent moves to farm the species under intensive pastoral grazing regimens has highlighted the desirability of more closely aligning peak pasture production in spring (September-November) with the high energy demands of lactation that normally occur in summer (December-March). Fertile oestrus would need to be induced up to 2 months before the onset of the natural breeding season to achieve this goal.

The absence of ovulation in ewes during the anoestrous season is due to failure of follicular maturation, reflecting inadequate release of luteinizing hormone $(\mathrm{LH})$ from the pituitary gland. $\mathrm{LH}$ release is partly regulated by gonadotrophin-releasing hormone (GnRH) secreted from the hypothalamus and the lack of adequate $\mathrm{LH}$ release during anoestrus probably involves diminished GnRH secretion (Karsch et al., 1980; Martin, 1984). Studies on progesterone-primed anoestrous ewes have demonstrated that a continuous low infusion rate $(125-250 \mathrm{ng} / \mathrm{h})$ of $\mathrm{GnRH}$ induced sustained elevations in basal plasma LH concentrations plus oestrus, ovulation and normal luteal development (McLeod et al., 1983). Infusion technology has been advanced recently by the development of small osmotic pumps which will deliver a contained solution at a constant rate for a minimum of 7 days when implanted into an animal. Wright et al. (1983) used this type of device to administer a constant infusion of 62.5 or $125 \mathrm{ng} \mathrm{GnRH/h}$ to progesterone-primed anoestrous ewes. 
This treatment induced oestrus and ovulation which culminated with successful conceptions, demonstrating that the technique was applicable in field as well as laboratory situations.

The present study investigates the induction of oestrus and ovulation in seasonally anoestrous fallow does by means two levels of GnRH infusion via osmotic minipumps after progesterone treatment.

\section{Materials and Methods}

Animals and management. Fourteen non-lactating failow does, $26(\mathrm{~N}=7)$ or $38(\mathrm{~N}=7)$ months of age, were drafted into a single mating group on 1 February 1984 . Seven of the does had run with a vasectomized buck during the 1983 breeding season. The remaining 7 does all fawned in December 1983 but had lost their fawns soon after birth. None of the does had shown any evidence of being reproductively abnormal.

A single, polled buck (26 months old) was introduced to the mating group on 7 February and remained with them until 3 May. Thereafter, the does were grazed with other does from other trials. The deer were contained in high-fenced paddocks $(0.25 \mathrm{ha})$ and grazed on ryegrass-clover pastures.

Treatment. A single silicone elastomer (polydimethylsiloxane) device impregnated with $0.5 \mathrm{~g}$ progesterone (CIDR [Controlled Internal Drug Release]; AHI Plastic Moulding Co., Hamilton, NZ) was inserted intravaginally into each doe on 7 February and removed on 20 February. At CIDR removal, a single osmotic minipump (Model 2001; Alzet Mini-Osmotic Pump; Alza Corp., Palo Alto, CA, U.S.A.), containing either a high $(\mathrm{N}=7)$ or low $(\mathrm{N}=7)$ concentration solution of synthetic GnRH (mol. wt. 1182.39; Peninsula Laboratories, Belmont, CA, U.S.A.), was implanted subcutaneously in the neck of each doe. The expired minipumps were removed on 9 March. For both insertion and removal of minipumps, a local anaesthetic (xylocaine hydrochloride $2 \%$ ) was administered subcutaneously at the implant site. The mean ( \pm s.d.) infusion (delivery) rate from the minipumps was $1.07 \pm 0.04 \mu \mathrm{l} / \mathrm{h}$ and the mean total fill volume was $238.5 \pm 9.9 \mu \mathrm{l}$ (Alza Corp.; quality control description of the batch used in this study), giving an effective infusion period of about 9 days. The two concentrations of $\mathrm{GnRH}$ were $250 \mu \mathrm{g} / \mathrm{ml}$ and $125 \mu \mathrm{g} / \mathrm{ml}$ and were made up in a $0.9 \%$ saline solution containing $0.75 \%$ bovine serum albumin (Sigma Chemical Comp., St Louis, MO, U.S.A.) to give calculated GnRH infusion rates of $250 \mathrm{ng} / \mathrm{h}$ ('high') and $125 \mathrm{ng} / \mathrm{h}$ ('low'), respectively. The two treatment groups were approximately balanced for doe age and reproductive history.

Detection of oestrus The buck was fitted with a ram mating harness (Fergus; Merck, Sharp \& Dohme NZ Ltd, Auckland, NZ). Red, blue or green crayons were replaced at least every 3rd day. Visual observations of the does to detect oestrous behaviour and record crayon mating marks were conducted at frequent intervals from an enclosed observation platform throughout the daylight hours from 20 to 27 February inclusive. Thereafter, observations to record mating marks were conducted at least twice daily while the buck was present with does.

Blood sampling. Does were collected into yards and blood sampled at 2- or 3-day intervals during CIDR insertion and every 2 nd day from CIDR removal to $15 \mathrm{March}$. Thereafter they were blood sampled weekly until $28 \mathrm{March}$. Blood $(\sim 10 \mathrm{ml})$ was collected into serum Vacutainers by jugular venepuncture while the deer were restrained in a special cradle device. Samples were chilled to $\sim 5^{\circ} \mathrm{C}$ and then centrifuged. The serum was transferred to glass vials and stored at $-10^{\circ} \mathrm{C}$ until assayed.

Progesterone radioimmunoassay. Progesterone was measured by a procedure similar to that described by Fairclough et al. (1975) and has been validated previously for these and other fallow deer serum samples (Asher, 1985). The progesterone antiserum (Ruakura $R_{2}$ ) was raised in a rabbit against progesterone-11-BSA conjugate and used at a final dilution of 1:3000. The only major 
cross-reaction of a wide range of steroids tested in the assay was cholesterol $(1 \cdot 5 \%)$. The sensitivity of the standard curve was $0.03 \mathrm{ng}$ per tube and the intra- and inter-assay coefficients of variation were $6.7 \%$ and $10 \cdot 6-11 \cdot 5 \%$ respectively (after Asher, 1985).

Statistical analysis. Differences between means were tested with Student's $t$ test.

\section{Results}

\section{Occurrence of oestrus and conception}

One doe was found to have lost its CIDR by the day of minipump implantation (low dose GnRH group) and subsequently failed to exhibit oestrus during the early trial period. One out of 6 remaining does (16.7\%) which received the low dose GnRH infusion and 5 out of 7 does (71.4\%) treated with the high dose exhibited oestrus between 71 and $120 \mathrm{~h}$ (23-25 February) after CIDR removal (Fig. 1a), with the single doe from the low dose group exhibiting oestrus at $96 \mathrm{~h}$.

Only one doe, which received the high dose of GnRH and exhibited oestrus $76 \mathrm{~h}$ after CIDR removal, conceived at the induced oestrus on 23 February, subsequently giving birth to a viable

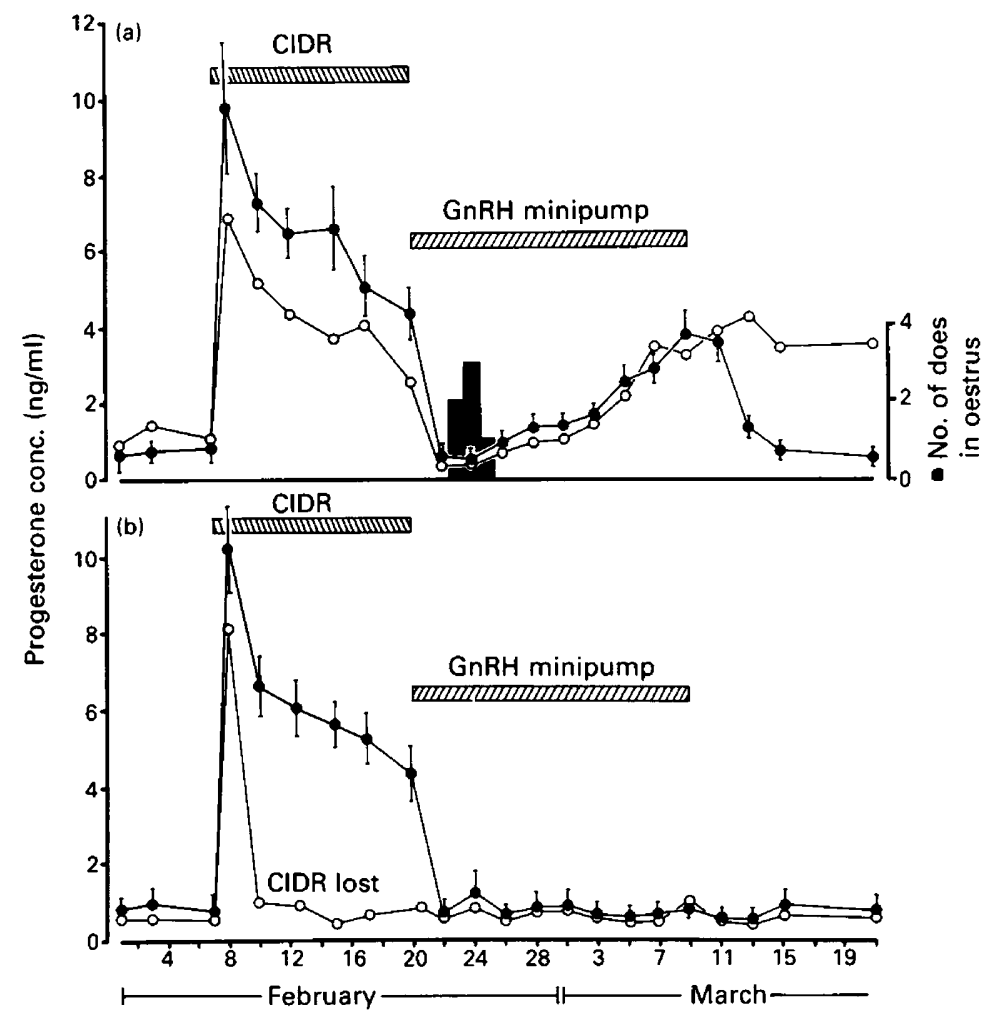

Fig. 1. Mean ( \pm s.e.m.) serum progesterone concentrations of fallow does, recorded during the last part of the anoestrous season. Occurrence of oestrus is displayed as a vertical bar graph and the periods of treatment with intravaginal CIDRs and GnRH minipumps are indicated by horizontal bars. (a) Does exhibiting oestrus but not conceiving $(\mathrm{N}=5 ;-0)$ and a doe exhibiting oestrus and conceiving $(\mathrm{O}-\mathrm{O})$. (b) Does not exhibiting oestrus $(\mathrm{N}=7$; - $)$ and a doe that lost its CIDR before minipump insertion $(\mathrm{O}-\mathrm{O}$ ). 
( $3.6 \mathrm{~kg}$ ) female fawn on 21 October ( 241 days gestation), this being about 6 weeks earlier than the start of the natural fawning season. The remaining does all conceived at spontaneously occurring oestrus in April and gave birth after normal gestation periods. The mean ( \pm s.d.) date of the spontaneous return oestrus was 23.5 April ( $\pm 4 \cdot 2$ days) and was not significantly different $(P>0 \cdot 1)$ from the mean date of first oestrus of 42 untreated does (mean $=25.9$ April \pm 4.0 days) in another trial in the same year (Asher, 1986).

\section{Progesterone profiles}

The mean serum progesterone profile of the 5 does that exhibited oestrus during GnRH treatment but failed to conceive at that oestrus is presented in Fig. 1(a). This includes the profile of the low-dose doe that exhibited oestrus, as it was apparently no different from the profiles of the high dose does. Mean progesterone concentrations during the period of CIDR insertion were higher than recorded during any subsequent period. After the induced oestrus mean serum progesterone concentrations increased from $\sim 0.5 \mathrm{ng} / \mathrm{ml}$ to maximum values of $\sim 3.8 \mathrm{ng} / \mathrm{ml}$ over 14 days and thereafter declined. There was no evidence of any further cyclic elevations of serum progesterone concentrations within the blood sampling period.

The serum progesterone profile following CIDR removal of the doe that conceived at induced oestrus (Fig. 1a) was similar to that of the non-conceiving does except that serum progesterone concentrations remained elevated $(>3.0 \mathrm{ng} / \mathrm{ml}$ ) after corpus luteum development.

Mean serum progesterone concentrations of does that were not observed to exhibit oestrus after treatment (Fig. lb) were also elevated during the period of CIDR insertion. However, mean values following CIDR removal and minipump implantation were uniformly low $(<1.0 \mathrm{ng} / \mathrm{ml})$.

The doe that lost its CIDR had elevated serum progesterone concentrations on the day after CIDR insertion but subsequent concentrations were low $(<1.0 \mathrm{ng} / \mathrm{ml}$; Fig. 1b).

\section{Discussion}

This trial has demonstrated that oestrus can be induced in non-lactating fallow does as early as 6 weeks before the natural rut by using a regimen of exogenous progesterone treatment followed by continuous infusion of sub-microgramme doses of GnRH.

The trial period represents the last portion of the anoestrous season in untreated fallow does. There is not usually any ovulatory activity until about 3 weeks before first overt oestrus in midApril (Asher, 1985). Although no control does were included in the trial it is unlikely that untreated does would have exhibited oestrus or ovulated during the trial period. The results showed that the higher rate of GnRH infusion $(250 \mathrm{ng} / \mathrm{h})$ was more effective than the lower rate $(125 \mathrm{ng} / \mathrm{h})$ in stimulating oestrus and ovulation following progesterone pretreatment. In contrast, sheep respond to infusion rates of $\mathrm{GnRH}$ as low as $62.5 \mathrm{ng} / \mathrm{h}$ (Wright et al., 1983).

The 6 fallow does that were observed to exhibit oestrus showed evidence of ovulation and subsequent normal luteal function in that they had a progesterone secretion profile $(\mathrm{N}=5)$ similar to that observed during the oestrous cycle of does during the breeding season (Asher, 1985), or sustained high serum progesterone values $(\mathrm{N}=1)$ as a result of conception. In these does the pituitary stimulation achieved by the imposed GnRH infusion regimen was apparently sufficient for development of a functional corpus luteum. In contrast there was apparently insufficient pituitary stimulation in the remaining 7 does ( 5 of which received the lower GnRH infusion rate) because they failed to show evidence of oestrus and normal luteal function.

The 5 does that exhibited elevated serum progesterone concentrations after induced oestrus reverted to an anoestrous and anovulatory state following the apparent luteal regression. This was indicated by their failure to exhibit further serum progesterone cycles. Similar results were obtained 
in studies utilizing pulsatile administration of GnRH to anoestrous ewes (McLeod et al., 1983; McNatty et al., 1984) and progestagen plus PMSG induction of oestrus and ovulation in anoestrous red deer hinds (Adam et al., 1985). Treatments that induce oestrus outside the breeding season will not necessarily initiate recurring reproductive cyclicity and may not advance the breeding season in the absence of conception. A low conception rate (16.7\%) of fallow does after induced oestrus has also been obtained with a progestagen plus PMSG treatment of anoestrous red deer hinds (Kelly $e t$ al., 1982; Adam et al., 1985). It is possible that male fertility and/or libido were suboptimal at the times of induced oestrus.

We thank Dr G. K. Barrell (Lincoln College), Dr J. L. Adam and Dr A. J. Peterson (Ruakura) for advice during this study; Mr A. M. Day for veterinary assistance; and M. Langridge, K. Hargreaves, H. Humble and other staff of the Ruakura Deer Unit for assistance in animal management and blood sampling.

\section{References}

Adam, C.L., Moir, C.E. \& Atkinson, T. (1985) Plasma concentrations of progesterone in female red deer (Cervus elaphus) during the breeding season, pregnancy and anoestrus. J. Reprod. Fert. 74, 631-636.

Asher, G.W. (1985) Oestrous cycle and breeding season of farmed fallow deer, Dama dama. J. Reprod. Fert. 75, $521-529$.

Asher, G.W. (1986) Studies on the reproduction of farmed fallow deer, Dama dama. Ph.D. thesis, University of Canterbury, New Zealand.

Chapman, D.I. \& Chapman, N. (1975) Fallow Deer: their History, Distribution and Biology. Terence Dalton Ltd, Lavenham.

Fairclough, R.J., Hunter, J.T. \& Welch, R.A.S. (1975) Peripheral plasma progesterone and utero-ovarian prostaglandin $F$ concentrations in the cow around parturition. Prostaglandins 9, 901-914.

Karsch, F.J., Goodman, R.L. \& Legan, S.L. (1980) Feedback basis of seasonal breeding: test of an hypothesis. J. Reprod. Fert. 58, 521-535.

Kelly, R.W., McNatty, K.P., Moore, G.H., Ross, D. \& Gibb, M. (1982) Plasma concentrations of LH, prolactin, oestradiol and progesterone in female red deer (Cervus elaphus) during pregnancy. J. Reprod. Fert. 64, 475-483.
Martin, G.B. (1984) Factors affecting the secretion of luteinizing hormone in the ewe. Biol. Rev. 59, 1-87.

McLeod, B.J., Haresign, W. \& Lamming, G.E. (1983) Induction of ovulation in seasonally anoestrous ewes by continuous infusion of low doses of GnRH. $J$. Reprod. Fert. 68, 489-495.

McNatty, K.P., Hudson, N., Gibb, M., Ball, K., Fannin, J., Kieboom, L. \& Thurley, D.C. (1984) Effects of long term treatment with LH on initiation of cyclic ovarian activity in seasonally anoestrous ewes. J. Endocr. 100, 67-73.

Wright, P.J., Clarke, I.J. \& Findlay, J.K. (1983) The induction of fertile oestrus in seasonally anoestrous ewes using a continuous low dose administration of gonadotrophin releasing hormone. Aust. vet. J. 60 , 254-255. 